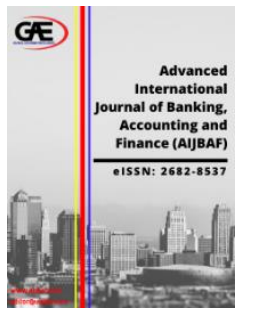

\author{
ADVANCED INTERNATIONAL JOURNAL OF \\ BANKING, ACCOUNTING AND FINANCE \\ (AIJBAF) \\ www.aijbaf.com
}

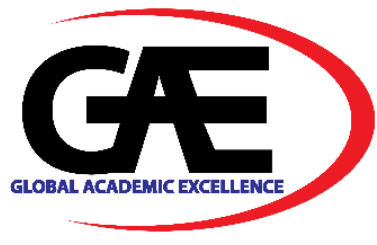

\title{
ZAKAT ACCOUNTING COURSE: VALUABLE INPUT TO HIGHER LEARNING INSTITUTIONS
}

\author{
Nurul Fatma Aziz@Awang ${ }^{1,}$ Nurshamimi Sabli ${ }^{2}$, Rohayu Yusop ${ }^{3}$ \\ 1 Faculty of Accountancy, Universiti Teknologi MARA (UiTM), Malaysia \\ Email: nurulfatma@uitm.edu.my \\ 2 Faculty of Accountancy, Universiti Teknologi MARA (UiTM), Malaysia \\ Email: nurshamimi@uitm.edu.my \\ 3 Faculty of Accountancy, Universiti Teknologi MARA (UiTM), Malaysia \\ Email: rohayu831@uitm.edu.my \\ * Corresponding Author
}

\section{Article Info:}

Article history:

Received date: 21.01 .2020

Revised date: 01.02 .2020

Accepted date: 12.09.2021

Published date: 15.09.2021

\section{To cite this document:}

Awang, N. F., Sabli, N., \& Yusop, R. (2021). Zakat Accounting Course: Valuable Input To Higher Learning Institutions. Advanced International Journal of Banking, Accounting, and Finance, 3 (8), 55-64.

DOI: $10.35631 /$ AIJBAF.38005.

This work is licensed under CC BY 4.0

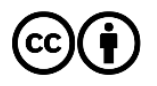

\begin{abstract}
:
The objective of this study is to investigate the factors that encourage students to choose Zakat Accounting as their elective course at one of the Higher Learning Institutions in Malaysia. Primary data for the study were collected using a self-administered questionnaire from three classes. Overall, a total of 59 respondents were engaged as the sample of this study. The findings revealed that the factors influencing the students' selection were personal interest in the subject matter, opportunity to learn a new area of accounting, ease of subject matter, quality of the lecturer teaching, and religious belief. The talk given by the Faculty was regarded as the most convincing source of information for the students in selecting the elective course. Although this study only focuses on one university in Malaysia, it could become a catalyst for future studies in the area of Zakat Accounting. Despite the limitation, it still provides some insightful findings of the students' acceptance determinants of an Islamic course in a university. In conclusion, this study hopes to provide invaluable input to the management of the Higher-Level Institutions on factors to consider before offering any new courses to students.
\end{abstract}

\section{Keywords:}

Elective Courses, Zakat Accounting, Students, Higher Learning Institution

\section{Introduction}

The demand for Islamic Accounting has increased due to the rise of Islamic Financial Institutions around the world (Amin et.al., 2009). Islamic Accounting has been introduced in 
Volume 3 Issue 8 (September 2021) PP. 55-64 DOI 10.35631/AIJBAF.38005

Malaysia Hala Tuju 3 to meet the growing need in this subject. Furthermore, knowledge of Islamic accounting is required and is a component of fardu kifaya. Since zakat is an element of Islamic religious education, a recent study by Osman, Suib, and Md Noor (2020) looked into society's current attitudes regarding child education. As a result, universities and colleges are now offering new Islamic education courses such as Islamic Accounting for Islamic Financial Institutions, Syariah Audit, Zakat Accounting, and Islamic Finance. Zakat Accounting is regarded as one of the most important courses since it mixes religious and technical knowledge (the understanding of zakat fiqh and calculation). All Muslims are required to pay zakat, which is one of the five pillars that Muslims must follow. Accounting students should be familiar with Zakat Accounting, as one of the reasons of generating financial reports in Islamic Accounting and to aid the calculation of zakat. Muhasabah al-zakah is the Arabic term for zakat accounting. Zakat Accounting is made up of five parts. First, to determine which assets that require zakat payment. Second, assess the state of assets that require zakat payment. Third, identify the proper zakat rate and calculate the zakat assessment on the assets involved. The fourth step is to collect zakat from certified zakat payers and distribute it to the eight categories of deserving recipients. Finally, to submit to the authorities a report on the collecting and distribution of zakat (Hamat, 2014).

Zakat Accounting is a new subject that has the potential to meet the need for Islamic accounting education in Malaysian universities. Zakat Accounting is unique since it incorporates ethical and religious components. It provides an alternative to traditional and secular accounting. The ethical components aid in the production of future accountants whose job is governed by Islamic law, potentially discouraging them from accepting bribes or engaging in fraud. In addition to accounting, companies require accountants who are well-versed in Islamic law. Accounting and zakat fiqh understanding are required for zakat assessment. An accountant who is aware with all of the requirements for a zakat-eligible asset will be able to compute the correct zakat amount to be paid. Furthermore, accountants who are knowledgeable in zakat evaluation may be able to influence more zakat payers from both personal and commercial revenue.

Since Islamic accounting courses are becoming increasingly popular in Malaysian higher education institutions, the goal of this research is to look into why accounting students choose the Zakat Accounting course as an elective subject. Understanding why students want to pursue a career in accounting is an important first step in attracting the best candidates. Many studies have been undertaken on accounting as a major course, but this is the first study on accounting as an elective subject.

\section{Literature Review}

Prior research demonstrated that a large number of scholars have looked into the factors for university students' academic decisions. The results of the research are uneven, with the majority of them focusing on major course selection rather than accounting students explicitly. Students are influenced by a variety of factors when deciding on a major. For example, students who excel at numbers, particularly mathematics, are more likely to pursue Accounting as a major (Abu Shawarib, 2010). In addition, students' prior experience in a related accounting subject will help to decide their accounting specialisation (Geiger and Ogilby, 2000). According to Kaur and Leen (2007), students choose a course that is well-known at a university. They discovered a link between a faculty member's teaching reputation and the choice of accounting as a major.

Copyright $\odot$ GLOBAL ACADEMIC EXCELLENCE (M) SDN BHD - All rights reserved 
Although various research have been conducted on the factors that influence students' decision to pursue accounting as a major, few studies have been conducted on the elective subject, notably in Islamic or Zakat Accounting. The benefit of adding the elective subject is that it supports a student-centered approach to education, which can help students learn more outside of their core classes. It could also be an opportunity for them to find out what they're interested in (Mikkonen et.al., 2009). Elective subjects have been demonstrated in studies to increase students' excitement and interest, which can improve learning quality (Krapp, 2002). While an elective topic might provide students with a considerable advantage, it is vital to remember that one of the most important conditions for this to occur is for students to be able to behave responsibly and independently when choosing their choices. Students may not be able to choose the ideal elective if they are not given adequate, thorough, and reliable information. Understanding the motivations of students when choosing an elective will help the institution build a better curriculum, improve learning and teaching quality, assign lecturers, and arrange enough facilities (Mayo and Miciak, 1991). Choosing the wrong elective can have a significant impact on students' engagement, individual accomplishment, and post-education employment opportunities.

The important of elective subject especially in accounting course was analysed by (Eva \& Vendula 2017) specifically on Taxation as an elective. The students preferred to learn Taxation as a separate subject or as an elective course with hands-on work that includes professional life and knowledge as employee, employer or businessman. Furthermore study by Greig (2018) on the High School Accounting curriculum in Queensland, addressed the subject offered supposed to be always updated with the twenty-first century skills by getting feedback from the accountants particularly. The need for new accounting courses resulted from factors such as business trends and the need for additional accountants' expertise. In general, accounting curricula were developed to fill the market's need for accountants from the businesses.

Nowadays, businesses play an important role to the society in term of the products and services they produced, the job opportunity they provide and the impact of their operations to the society. Therefore, it is very crucial for accounting educators to provide students with opportunities to develop business skills, expose the powerful effects of business decisions and actions on society and the potential damage business can cause. One of the ways are through the teaching of ethics and corporate social responsibility (CSR) to help accounting students to better understand the importance of business action towards society (Kolodinsky, Madden, Zisk, \& Henkel, 2009) and educate them to deal with these challenges.

Furthermore, the rising needs for ethics in accounting courses in the accounting curriculum is a result of the accounting scandals and corporate failures. Even though ethics in accounting education cannot teach moral values or ethical attitudes, it can help to raise awareness of ethical issues. Ethics education also improves a student's ability to solve ethical dilemmas with a minimum harm. Every day, a company's manager faces a variety of ethical issues and ethical dilemmas. Overall, ethics in accounting education provides basis for awareness of ethical behaviours, identifying ethical issues, and resolving ethical dilemmas (Evren Dilek Şengur 2017) as well as increasing students' ethical awareness, as a way to predict ethically minded future professional behaviour (Tormo-Carbó, Seguí-Mas \& Oltra 2018). This is in line with the UNESCO (2005), under the United Nations Decade of Education for Sustainable Development (UN DESD) which aims to integrate the principles, values, and practices of sustainable Copyright $\odot$ GLOBAL ACADEMIC EXCELLENCE (M) SDN BHD - All rights reserved 
Volume 3 Issue 8 (September 2021) PP. 55-64 DOI 10.35631/AIJBAF.38005

development into all aspects of education and learning, in order to address the social, economic, cultural and environmental challenges that we face today (Larrán Jorge, Andrades Peña \& Muriel de los Reyes 2015).

In this regard, the Malaysian Institute of Accountants has developed the Competency Framework to monitor and regulate the quality of all accounting talent. Among areas that need to be a close attention are valuation, shariah audit and insolvency (Accountants Today, 2017). Islamic accounting courses including zakat accounting are important to enhance the knowledge of accounting students and practitioners in preparation of accounting reports and financial statements of the Islamic institutions such as Islamic banks, takaful, zakat and Ar-rahnu (Islamic pawn)(Hazianti Abdul Halim 2017) and exposed the students on the importance of ethics and value according to the Islamic principles. In a study conducted by Siswantoro (2015), Indonesian students taking Islamic accounting course for their elective paper has less awareness on Islamic accounting, as they perceived that Islamic accounting course is just as similar as any other new subject enrolled by them. Since, there is a lack of studies on the Islamic accounting which cover the value of Islamic principles and ethics, this study looks upon the student's motivation to choose zakat accounting as one of the Islamic accounting field.

Past literature highlighted three main factors influencing students in selecting an elective: intrinsic, extrinsic, and the elective subject characteristics (Hedges, Pacheco, \& Webber, 2014). Intrinsic factor is when the students have an underlying curiosity and interest in the course. Meanwhile, extrinsic motivation is the external factor, which provides motivation and satisfaction that the subject did not provide to the student (Elton, 1998). An example of extrinsic motivation was a study on Islamic accounting course, which has been introduced at Universitas Indonesia as one of the initiatives to meet the competency requirement of Islamic Accounting Certification test conducted by the Indonesian Institute of Accountants (Siswantoro, 2015).

It is common to think that students will choose modules or subjects based on their interest. Elton (1998) highlighted that intrinsic motivation has huge outcomes since the students are keen to work enthusiastically and independently, engage with the material, have depth understanding of the meaning, can connect with the previous studies subjects and with the real practices. As such, students who choose their preferred subjects will be able to have better understanding of the course and score good marks in the examination.

Apart from personal interest on the subject, students might choose an elective for other external reasons. For instance, a student may choose a less preferred elective, but likely to have a higher chance of getting better result or better career opportunity. Although the students do not have any or little interest in the subject or the lecturer is deemed boring, the external factor of a higher chance of getting good marks will keep the students motivated taking the subject. The characteristics of the elective subject will also affect the students' decision. For example, a student with poor mathematical skill would choose a writing-based elective that does not require much calculation.

Another example was an empirical study conducted by Kholid, Tumewang and Salsabilla (2020), which revealed that on top of greater job opportunities, students' perception on the Islamic technical skills as well as level of Islamic religiosity contributed positively to the students' intention to become Islamic accountant. This study in fact in line and has consider all Copyright (C) GLOBAL ACADEMIC EXCELLENCE (M) SDN BHD - All rights reserved 
Volume 3 Issue 8 (September 2021) PP. 55-64 DOI 10.35631/AIJBAF.38005

the above three contributing factors of choosing elective course, particularly the Islamic accounting course. This study was also in line with a prior study by Halim (2017) who has discovered a positive response from the accounting student on the need of Islamic accounting knowledge in becoming future accountants. Hence, in securing a job in the current and future market environment, the need for specific knowledge such as Islamic accounting is highly important to the accounting student nowadays.

Another factor to ponder specifically in choosing Islamic elective course is how the educators can help student to instill the Islamic values in all life practices (Sari, Rahmawati \& Al-Rasyid, 2019). Through the philosophical values of a French movie, the authors stressed that Islamic accounting education will not provide adequate knowledge to the students if it only covers the technical capabilities in the word "Sharia" to understand the Islamic accounting. Understanding accounting by relating it to emotional and spiritual values are hence vital to students in nurturing their awareness to Islamic substance of Tawheed. This significant factor has also been supported by Ilham (2020) in his review towards realignment of the current Islamic education system.

\section{Methodology}

A questionnaire was created and distributed to the Bachelor of Accounting students, who selected Zakat Accounting as their preferred elective course. The purpose of Zakat Accounting specifically is to provide students with a proper understanding of the concepts of Zakat, methods of evaluation, measurement, and accounting treatment for Zakat based on various opinions of fiqh scholars and issues in Zakat management. The students need to choose their first elective in their second year, between the Islamic Accounting paper and other Accounting paper. In their third year, Zakat Accounting is among the four choices available. The questionnaires are divided into two sections: 1) Section A is on the demographic information, and 2) Section B is on the preference response.

\section{Result}

A total of 59 respondents were selected from three different classes taught by two different lecturers of the same Zakat elective course. Of the 59 respondents, 44 were females, and 15 were males. This reflects an unequal distribution of $75 \%$ female and $25 \%$ male students. Fiftysix of the respondents were aged between 22 and 23 years old, two students were 20-21 years, and one student was more than 24 years old. The questionnaires were adapted from a study by Crampton, Walstrom and Schambach (2006) on factors influencing major selection by a college of business students. The questionnaires were selected, reviewed, and modified to suit this study's objective. Using a 5-point Likert-type scale, the students were asked to reflect or indicate their level of knowledge on career opportunities in various Accounting disciplines when they graduated from university. 
Volume 3 Issue 8 (September 2021) PP. 55-64 DOI 10.35631/AIJBAF.38005

Table 1: Responses To The Question:

How Knowledgeable and Informed (Aware) Were You About These Possible Careers in Accounting (In Order from The Most to Least Knowledgeable).

\begin{tabular}{lc}
\hline \multicolumn{1}{c}{ Area } & $\begin{array}{c}\text { Mean Reported Career } \\
\text { Knowledge Level* }\end{array}$ \\
\hline Academician (Teacher/Lecturer) & 4.29 \\
\hline Chartered Accountant & 4.25 \\
\hline Tax Advisor & 4.17 \\
\hline Company Secretary & 3.88 \\
\hline Chartered Management Accountant & 3.75 \\
\hline Chartered Public Finance Accountant & 3.68 \\
\hline Management Consultant & 3.53 \\
\hline Business Advisor & 3.46 \\
\hline Actuarial Analyst & 3.00 \\
\hline
\end{tabular}

$* 1=$ Not at all aware; $5=$ Extremely aware

Table 1 shows that the respondents were most knowledgeable about the possible careers in academic lines, such as teacher and lecturer, Chartered Accountant, Tax Advisor, and Company Secretary. They were least knowledgeable about the potential job as Chartered Management Accountant, Chartered Public Finance Accountant, Management Consultant, Business Advisor, and an Actuarial Analyst.

Table 2 Responses To The Question:

How Important are These Information Sources When You Select the Elective Course? (In Order of Importance From Most to Least)

\section{Information Source}

Average

Importance*

Presentations by Faculty (through Coordinator, Lecturer) 3.86

$\begin{array}{ll}\text { Invited speakers } & 3.86\end{array}$

Online job listing 3.81

Newspaper article related to the course $\quad 3.68$

$\begin{array}{ll}\text { Information on the Faculty website } & 3.61\end{array}$

Information on the internet other than the Faculty's website 3.59

Information on the Faculty Facebook page 3.51

Television or movie portrayal of the occupation related to the course $\quad 3.29$

*1 = Least importance; 5 = Most importance

Table 2 shows the impact of the different information sources on guiding students in selecting their elective subjects. On a scale of $1-5,2.5$ is the midpoint. All the information sources listed were considered important, by having a score more than the midpoint. The most influential information source came from the presentation by a faculty member, invited speakers, and online job listing. 
Volume 3 Issue 8 (September 2021) PP. 55-64 DOI 10.35631/AIJBAF.38005

Table 3 Responses to The Question: How Important are These Factors When You Select the Elective Course (In Order of Importance From Most to Least).

Factor

Personal interest in the subject matter

Opportunity to learn a new area of accounting

(previously was Conventional Accounting)

\begin{tabular}{ll} 
Ease of subject matter - Easy for me & 4.15 \\
Quality of the teaching lecturer & 4.15 \\
\hline Religious belief & 4.15 \\
\hline The job security of related occupations (e.g., Accountant) & 3.97 \\
\hline Opportunity to participate in many activities & 3.97 \\
\hline Probability of working in the field after graduation & 3.81 \\
\hline Career Interest Tests/Assessments & 3.78 \\
$\begin{array}{l}\text { Probability of Graduating with Honors (this course could } \\
\text { contribute a good grade) }\end{array}$ & 3.76 \\
\hline The difficulty of subject matter - Difficult for most people & 3.75 \\
Friends & 3.75 \\
\hline Occupational growth forecasts & 3.73 \\
\hline Classmates & 3.68 \\
\hline Lecturers & 3.59 \\
\hline Parents & 3.31 \\
\hline Performance in the previous related course (Islamic Accounting) & 3.27 \\
Family members other than parents & 3.02 \\
\hline
\end{tabular}

* 1 = Least importance; 5 = Most importance

Table 3 shows the importance of factors that affected the respondent choices in selecting the Elective Course. The most important factors are personal interest in the subject matter, opportunity to learn a new area of accounting, ease of subject matter, quality of teaching lecturer, and religious belief. Other factors that also influenced students in choosing their Elective Course are job security of related occupations, opportunity to participate in many activities, probability of working in the field after graduation, career assessments, and difficulty of the subject matter. The top eleven factors are related to self-interest, career outcomes, and characteristics of the profession itself.

\section{Discussion and Conclusion}

The respondents were most knowledgeable about a career as an academician, which might be due to the influence of their favourite professors at the University. This is followed by the career of Chartered Accountant and Tax Analyst. It indicates their good exposure and preparation towards becoming Professional Accountant. Meanwhile, for the information that influenced students in selecting the Elective subject, talk given by Faculty is regarded as the most convincing, followed by the talk presented by invited speakers. This finding explains the importance of first-hand information since it is more reliable and lesser chance of misunderstanding. Students also referred to the online job listings when considering an elective. An elective that has a place in the job market and ample job prospect will attract more students' enrollment. 
Volume 3 Issue 8 (September 2021) PP. 55-64

DOI 10.35631/AIJBAF.38005

The top factor that influences students in selecting the elective is the intrinsic factor, which is self-interest on the subject. Consistent with the study by Samara (2015), the main factor for a course choice was their genuine interest in the subject matter. It is good for the students to consider their preference first before considering the opinion of others since the study is mainly about their future. Students that have an interest in a field are more likely to be successful in that field since interest can lead to high motivation to achieve dreams (Uyar, Gunormus, \& Kucey, 2011). Samara (2015) explained the choice made by the student was not only involved the students' interest in the subject but also included their perception of the difficulty of the course. Students tended to select an elective, in which they deemed they could perform well and do not require too much effort or less difficult. The next influences came from the subject itself, such as ease of the subject, quality of the lecturers, and job security related to the subject. Uyar et al. (2011) asserted that elective selection might be influenced by the students' perception of job opportunities. The high chance of getting a job related to the course will encourage students to choose the elective. This is also supported by recent study by Kholid et al. (2020) who have explored and proved empirically on the student's motivation factor of becoming Certified Sharia Accountant in Indonesia. Finally, influence also came from surroundings factors, such as parents and friends. This is supported by Kim et al. (2002), which revealed the least selected factors for major selection included the influence of peers and parents.

The aim of introducing the electives subject is to provide a relevant and quality education to meet the current demand. This study provides some implications that can help academic management department to plan and attract more students to join the course. The findings could guide the educators in the designing and promoting the courses, and for university administrators, in allocating space and teaching resources (Ting \& Lee, 2012). First implication to Higher-Learning Institutions' management is to design courses that reflect the students' needs and preferences. Second, educators can arrange supportive activities for those who do not select certain elective courses due to perceived difficulty of the field. Thirdly, accounting departments could invite professionals to give talks about job opportunities in the field, encourage and motivate students by giving real life examples and related success stories. In addition, the universities may build a connection between education and work life by creating good relationships with the business world. Faculty members must be kept updated with the current information on career prospects and convey the information to the students.

Furthermore, lecturers and staffs should always motivate students to be more interested in the subject (Samara, 2015). Indeed, they play an important role in the development of the students' positive interest and self-belief, and students' motivation to work hard and be persistent. Good design and structure of elective courses offer a different field of subjects that could build up students' competency and personal development. For instance, acquiring knowledge in zakat accounting will add value to the accounting students, which will give them a competitive edge in the job market of their preferred jobs. Furthermore, the opportunity for the student to specialise in a field is good for their career development and will motivate them to excel in the elective subjects. 


\section{References}

Abu, S. S. (2010). The factors that affect the students' decisions to choose accounting as a major field of study. Islamic University Journal, 18(1), 689-716.

Amin H, Abdul Rahim A. R, Ramayah T. (2009), What makes undergraduate students enroll into an elective course? The case of Islamic accounting, International Journal of Islamic and Middle Eastern Finance and Management, Vol. 2 No. 4, pp. 289-304

Crampton, W.J., K.A. Walstrom \& T.P. Schambach, (2006). Factors influencing major selection by college of business students. Issues in Information Systems, 7(1): 226 230.

Elton, L. (1988). Student motivation and achievement. Studies in Higher Education, 13(2), 215-221.

Eva, K. \& Vendula, K. 2017. the Factors Influencing College Students' Choice of Elective Subjects. Journal of Competitiveness 9(4): 40-49.

Evren Dilek Şengur. 2017. Accounting Ethics Education in Developing Countries: the Extent of Accounting Ethics Education in Turkey. Journal of International Social Research 10(53): 820-825.

Geiger, M. A., \& Ogilby, S. M. (2000). The first course in accounting: student's perceptions and their effect on the decision to major in accounting. Journal of Accounting Education, 18, 63-78.

Greig, P.C. 2018. Accounting: a case study of an elective subject in the Queensland senior high school curriculum.

Halim, H. A. (2017). Understanding and awareness of Islamic Accounting: The case of Malaysian accounting undergraduates. International Journal of Academic Research in Accounting, Finance and Management Sciences, 7(4), 33-39.

Hamat, Z., (2014). Sustainable Zakat Accounting in Malaysia: An Analysis. Mediterranean Journal of Social Science Vol. 5 No. 19 (August): 139-146.

Hedges, M., Pacheco, G. A., \& Webber, D. J. (2014). What determines students' choices of elective modules? Economics working paper series, 1307. Bristol: University of the West of England.

Ilham, D. (2020). The challenge of Islamic Education and how to change. International Journal of Asian Education, 1(1), 15-20.

Kaur, M., \& Leen, E. Y. (2007). Factors Influencing Undergraduates' Choice of Business Major. INTI International University College.

Kholid, M. N., Tumewang, Y. K. \& Salsabilla, S. (2020). Understanding Students' Choice of Becoming Certified Sharia Accountant in Indonesia. Journal of Asian Finance, Economics and Business, 7(10), 219-230.

Kim, D., Markham, F.S. \& Cangelosi, J.D. (2002), "Why students pursue the business degree: A comparison of business majors across universities", Journal of Education for Business, 78(1), pp. 28-32.

Krapp A. (2002) Structural and Dynamic Aspects of Interest Development: Theoretical Considerations from an Ontogenic Perspective. Learn Instr. 12:383-409.

Larrán Jorge, M., Andrades Peña, F.J. \& Muriel de los Reyes, M.J. 2015. Factors Influencing the Presence of Ethics and CSR Stand-alone Courses in the Accounting Masters Curricula: An International Study. Accounting Education 24(5): 361-382.

Mayo MA, \& Miciak A.(1991). The decision-making process underlying curriculum revision. J Mark Educ. 13(3):21-32. 
Volume 3 Issue 8 (September 2021) PP. 55-64 DOI 10.35631/AIJBAF.38005

Mikkonen J,, Heikkilä A, Ruohoniemi M, Lindblom-Ylänne S. (2009), “I Study Because I'm Interested": University Students' Explanations s for Their Disciplinary Choices. Scand J Educ Res. 53(3):229-44.

Osman, M. F., Suib, S. \& Md Noor, N. H. (2020). The function of the zakat funds continuance modal insan in their sustainable in Islamic pedagogy. Journal of Critical Reviews, 7(6), $526-530$.

Ting, D. H., \& Lee, Ch. K. Ch. (2012). Understanding Students' Choice of Electives and Its Implications. Studies in Higher Education, 37 (3), 309-325.

Tormo-Carbó, G., Seguí-Mas, E. \& Oltra, V. 2018. Business ethics as a sustainability challenge: Higher education implications. Sustainability (Switzerland) 10(8): 1-17.

Sari, A. F. K., Rahmawati \& Al-Rasyid, H. (2019). Le Grand Voyage: A Great Journey to Liberate Islamic Accounting Education from Utilitarianism and Secularism. Journal of Accounting and Business Education, 4 (1), 45-57.

Samara, F. (2015) Factors Influencing Students' Choice of Elective Science Courses: A Case Study from the American University of Sharjah. Open Journal of Social Sciences, 3, 93-99.

Siswantoro, D. (2015). Perception and awareness of Islamic accounting: student perspectives. Quality Assurance in Education, 23(3), 306-320.

Uyar, A., Gungormus, A. H., \& Kuzey, C. (2011). Factors Affecting Students Career Choice In Accounting: The Case Of A Turkish University. American Journal of Business. 